\title{
Modelling sediment export, retention and reservoir sedimentation in drylands with the WASA-SED model
}

\author{
E. N. Mueller ${ }^{1}$, A. Güntner ${ }^{2}$, T. Francke ${ }^{1}$, and G. Mamede $^{3}$ \\ ${ }^{1}$ Institute of Geoecology, University of Potsdam, Potsdam, Germany \\ ${ }^{2}$ Helmholtz Centre Potsdam - GFZ German Research Centre for Geosciences, Potsdam, Germany \\ ${ }^{3}$ Department of Environmental and Technological Sciences, Federal University of Rio Grande do Norte, Mossoró, Brazil \\ Received: 4 September 2008 - Published in Geosci. Model Dev. Discuss.: 2 October 2008 \\ Revised: 19 November 2009 - Accepted: 22 March 2010 - Published: 8 April 2010
}

\begin{abstract}
Current soil erosion and reservoir sedimentation modelling at the meso-scale is still faced with intrinsic problems with regard to open scaling questions, data demand, computational efficiency and deficient implementations of retention and re-mobilisation processes for the river and reservoir networks. To overcome some limitations of current modelling approaches, the semi-process-based, spatially semi-distributed modelling framework WASA-SED (Vers. 1) was developed for water and sediment transport in large dryland catchments. The WASA-SED model simulates the runoff and erosion processes at the hillslope scale, the transport and retention processes of suspended and bedload fluxes in the river reaches and the retention and remobilisation processes of sediments in reservoirs. The modelling tool enables the evaluation of management options both for sustainable land-use change scenarios to reduce erosion in the headwater catchments as well as adequate reservoir management options to lessen sedimentation in large reservoirs and reservoir networks. The model concept, its spatial discretisation scheme and the numerical components of the hillslope, river and reservoir processes are described and a model application for the meso-scale dryland catchment Isábena in the Spanish Pre-Pyrenees $\left(445 \mathrm{~km}^{2}\right)$ is presented to demonstrate the capabilities, strengths and limits of the model framework. The example application showed that the model was able to reproduce runoff and sediment transport dynamics of highly erodible headwater badlands, the transient storage of sediments in the dryland river system, the bed elevation changes of the $93 \mathrm{hm}^{3}$ Barasona reservoir due to sedimentation as well as the life expectancy of the reservoir under different management options.
\end{abstract}

\section{Correspondence to: E. N. Mueller} (eva.mueller@uni-potsdam.de)

\section{Introduction}

In drylands, water availability often relies on the retention of river runoff in artificial lakes and reservoirs. Such regions are exposed to the hazard that the available freshwater resources fail to meet the water demand in the domestic, agricultural and industrial sectors. Erosion in the headwater catchments and deposition of the eroded sediments in reservoirs frequently threatens the reliability of reservoirs as a source of water supply. Erosion and sedimentation issues have to be taken into account when analysing and implementing long-term, sustainable strategies of land-use planning (e.g. management of agricultural land) and water management (e.g. reservoir construction and management). The typical scale relevant for the implementation of regional land and water management is often that of large basins with a size of several hundreds or thousands of square kilometres.

Considering the potential impacts of changing climatic or physiographic boundary conditions on water availability and reservoir sedimentation, numerical modelling tools can help to explain and predict possible future changes to water and sediment dynamics of large river basins. For this purpose, a wide range of erosion and sediment transport models has been developed for the micro- to macro-scale over the last decades. The complexity of such models varies with the detail of spatial and temporal process representation, ranging from models representing hillslope processes for individual storm events or seasons, e.g. the WEPP model by Nearing et al. (1989) or EROSION-2D (Schmidt, 1991), to models designed for the catchment scale (e.g., the MEDALUS model, Kirkby, 1997; LISEM, De Roo et al., 1996; Jetten, 2002; EUROSEM, Morgan et al., 1998), up to large catchment scale models that model water and sediment fluxes for entire basins and longer time periods such as SWRRB (Arnold et al., 1989), SWIM (Krysanova et al., 2000), LASCAM

Published by Copernicus Publications on behalf of the European Geosciences Union. 
(Sivapalan et al., 1996) and SWAT (Neitsch et al., 2002). The latter, meso-scale modelling approaches often suffer from a problematic spatial representation of individual hillslope components in the headwater catchments, where most of the erosion occurs: the larger the modelling domain, the more averaging over spatial information occurs. The spatially semi-distributed SWAT model (Neitsch et al., 2002), for example, uses hydrologic response units to group input information in regard to land-use, soil and management combinations, thus averaging out spatial variations along the hillslope and topological information essential for sediment generation and transport. In comparison, grid-based models such as the LISEM model (Jetten, 2002) may incorporate a higher degree of spatial information, but are often limited in their applicability due to computing time (for small grid sizes) and lack of exhaustive spatial data, which makes their application at the meso-scale inappropriate.

Both types of models fail to enable the quantification of sediment transfer from erosion hotspots of erosion, i.e. small hillslope segments that contribute a vast amount to the total sediment export out of a catchment but at the same time cover only a rather small part of the total area, such as badland hillslopes or highly degraded slopes which are often found in dryland settings (e.g. Gallart et al., 2002). Besides the spatial representation of erosion hotspots, current modelling frameworks often lack an integrated representation of all components of sediment transport in meso-scale basins, such as retention and transient storage processes in large reservoirs, reservoir networks and in a (potentially ephemeral) river network.

To enable regional land and water management with regard to sediment export in dryland settings, it was therefore decided to develop a sediment-transport model that:

- incorporates an appropriate scaling scheme for the spatial representation of hillslope characteristics to retain characteristic hillslope properties and at the same time is applicable to large regions (hundreds to thousands of $\mathrm{km}^{2}$ );

- integrates sediment retention, transient storage and remobilisation descriptions for the river network (with a potential ephemeral flow regime) and large reservoirs and reservoir networks with the specific requirements of water demand and sedimentation problems of dryland regions;

- includes reservoir management options to calculate the life expectancy of reservoirs for different management practises; and

- is computationally efficient to cope with large spatial and temporal extent of model applications.

For this purpose, the WASA-SED (Water Availability in Semi-Arid environments - SEDiments) model has been developed and its structure, functioning and application is pre- sented here. This paper describes the model as of March 2010 (Version 1, revision 30). It consists of two main parts: firstly, the numerical descriptions of the spatial representation and the erosion and sediment transport processes in the hillslope, river and reservoir modules of WASA-SED are given. Secondly, a model application is evaluated for the Isábena catchment $\left(445 \mathrm{~km}^{2}\right)$ in the Pre-Pyrenees, simulating and discussing model performance and its limitations for badland hotspot erosion, transient storage of sediment in the riverbed, bed elevation change in the reservoir and management options for different life expectancies of a large reservoir.

\section{Numerical description of the WASA-SED model}

\subsection{Spatial representation of landscape characteristics}

The WASA-SED model is designed for modelling at the meso-scale, i.e. for modelling domains of several hundreds to thousands of square kilometres. It uses a hierarchical topdown disaggregation scheme developed by Güntner (2002) and Güntner and Bronstert (2004) that takes into account the lateral surface and sub-surface flow processes at the hillslope scale in a semi-distributed manner (Fig. 1). Each subbasin of the model domain is divided into landscape units that have similar characteristics regarding lateral processes and resemblance in major landform, lithology, catena profile, soil and vegetation associations. Each landscape unit is represented by a characteristic toposequence that is described with multiple terrain components (lowlands, slope sections and highlands) where each terrain component is defined by slope gradient, length, and soil and vegetation associations (soil-vegetation components). Within and between terrain components, the vertical fluxes for typical soil profiles consisting of several soil horizons and the lateral redistribution of surface runoff are taken into account.

For a semi-automated discretisation of the model domain into landscape units and terrain components, the software tool LUMP (Landscape Unit Mapping Program) is available (Francke et al., 2008). LUMP incorporates an algorithm that delineates areas with similar hillslope characteristics by retrieving homogeneous catenas with regard to e.g. hillslope shape, flow length and slope (provided by a digital elevation model), and additional properties such as for soil and landuse and optionally for specific model parameters such as leaf area index, albedo or the occurrence of special geomorphological features (bare rocks, badland formations, etc.). In contrast to methods based on mere intersection of multiple input layers, LUMP preserves information on the distribution of input properties in relation to the river network and their topographic position and, at the same time, allows an upscaling of small-scale hillslope properties into regional landscape units. The LUMP tool is linked with the WASA-SED parameterisation procedure through a data-base management tool, 


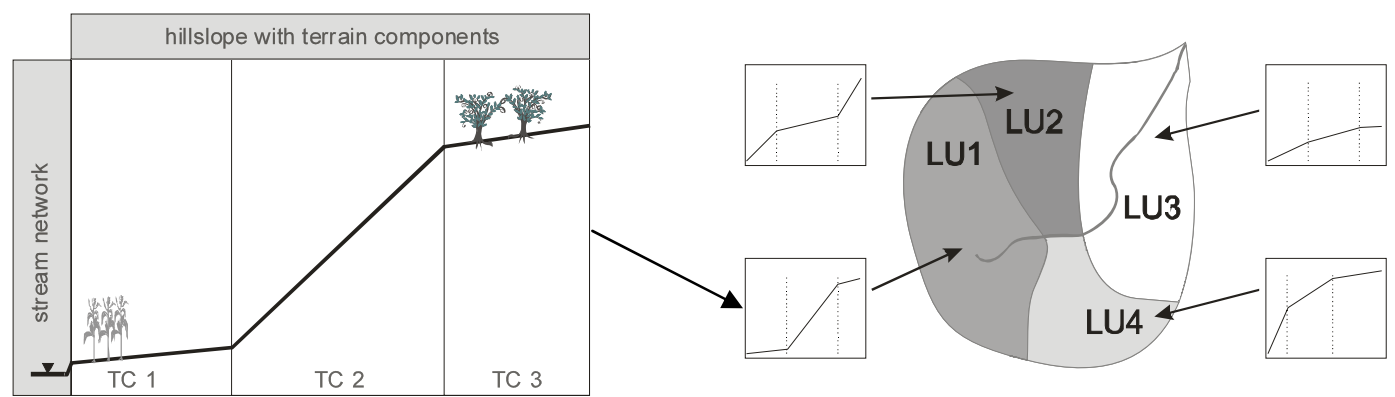

(a)

(b)

Fig. 1. Spatial discretisation of the WASA-SED model (adapted after Güntner, 2002): an example with 3 terrain components (TC) describing a catena and 4 landscape units (LU) describing a sub-catchment.

which allows to process and store digital soil, vegetation and topographical data in a coherent way and facilitates the generation of the required input files for the model.

The advantage of the spatial concept in the WASA-SED model is that it captures the structured variability along the hillslope essential for overland flow generation and erosion. LUMP thus enables the incorporation of erosion hotspots in the parameterisation procedure. For example, the specific characteristics of small hillslope segments that exhibit extreme rates of erosion for geological or agricultural reasons can be retained in a large-scale model application. The upscaling approach preserves a high degree of process-relevant details (e.g. intra-hillslope profile and soil distribution) while maintaining a slim demand in computational power and storage.

\subsection{Hydrological module of the WASA-SED model}

The hydrological model part of WASA-SED at the hillslope scale is fully described by Güntner (2002) and Güntner and Bronstert (2004). For daily or hourly time steps, the hydrological module calculates for each soil-vegetation component in each terrain component the following processes: interception losses, evaporation and transpiration using the modified Penman-Monteith approach (Shuttleworth and Wallace, 1985), infiltration with the Green-Ampt approach (Green and Ampt, 1911), infiltration-excess and saturation-excess runoff as well as its lateral redistribution between individual soilvegetation components and terrain components, soil moisture and soil water changes for a multi-layer storage approach, subsurface runoff and ground water recharge with a linear storage approach (Güntner, 2002).

\subsection{Sediment generation and transport processes in the hillslope module}

The sediment module in WASA-SED provides four erosion equations of sediment generation by using derivatives of the
USLE equation (Wischmeier and Smith, 1978), which can be generalised as (Williams, 1995):

$E=\chi K \operatorname{LSC} P \operatorname{ROKF} A$

where $E$ is erosion (t), $K$ the soil erodibility factor (t hah ha ${ }^{-1} \mathrm{MJ}^{-1} \mathrm{~mm}^{-1}$ ), LS the length-slope factor (-), $C$ the vegetation and crop management factor $(-), P$ the erosion control practice factor (-), ROKF the coarse fragment factor $(-)$ as used in the USLE and $A$ the area of the scope (ha). $\chi$ is the energy term that differs between the USLE-derivatives, which are given below. It computes as (Williams, 1995):

$$
\begin{aligned}
\text { USLE } & \chi & =\mathrm{EI} \\
\text { Onstad-Foster } & \chi & =0.646 \mathrm{EI}+0.45\left(Q_{\text {surf }} q_{\mathrm{p}}\right)^{0.33} \\
\text { MUSLE } & \chi & =1.586\left(Q_{\text {surf }} q_{\mathrm{p}}\right)^{0.56} A^{0.12} \\
\text { MUST } & \chi & =2.5\left(Q_{\text {surf }} q_{\mathrm{p}}\right)^{0.5}
\end{aligned}
$$

where EI is the rainfall energy factor $\left(\mathrm{MJ} \mathrm{mm} \mathrm{ha} a^{-1} \mathrm{~h}^{-1}\right)$, $Q_{\text {surf }}$ is the surface runoff volume (mm) and $q_{\mathrm{p}}$ is the peak runoff rate $\left(\mathrm{mm} \mathrm{h}^{-1}\right)$. In contrast to the original USLE, the approaches (3-5) incorporate the surface runoff $Q_{\text {surf }}$ (calculated by the hydrological routines) in the computation of the energy component. This improves the sediment modelling performance by eliminating the need for a sediment delivery ratio (SDR) and implicitly accounts for antecedent soil moisture (Neitsch et al., 2002). $E$ is distributed among the user-specified number of particle size classes, according to the mean composition of the eroded horizons in the area.

WASA-SED allows applying any of the listed erosion equations either at the sub-basin or the terrain component scale. In the former case, the USLE factors (see Eq. 1) result from area-weighted means throughout the sub-basin and cumulatively for the LS-factor as proposed by Foster and Wischmeier (1974, in Haan et al., 1994). If applied at the terrain component scale, the specific factors of each terrain component are used and sediment routing between terrain components is performed: any sediment mass $\operatorname{SED}_{\text {in }}(t)$ coming from upslope areas is added to the generated sediment mass 
$E$ to obtain the sediment yield SY (t) of a terrain component. SY is limited by the transport capacity $q_{\mathrm{s}}(\mathrm{t})$ of the flow leaving the terrain component:

$\mathrm{SY}=\operatorname{minimum}\left(E+\mathrm{SED}_{\mathrm{in}}, q_{\mathrm{s}}\right)$

Two options are available to calculate the transport capacity $q_{\mathrm{s}}$ :

(a) With the sediment transport capacity according to Everaert (1991):

if $D_{50} \leq 150 \mu \mathrm{m}: q_{\mathrm{s}}=1.50 \times 10^{-5} \Omega^{1.07} D_{50}^{0.47} \mathrm{~W}$

if $D_{50}>150 \mu \mathrm{m}: q_{\mathrm{s}}=3.97 \times 10^{-6} \Omega^{1.75} D_{50}^{-0.56} \mathrm{~W}$,

with $\Omega=(\rho g p S)^{1.5} / R^{2 / 3}$

where $\Omega$ is the effective stream power $\left(\mathrm{g}^{1.5} \mathrm{~s}^{-4.5} \mathrm{~cm}^{-2 / 3}\right)$ computed within the hydrological routines of WASA-SED, $D_{50}$ is the median particle diameter $(\mu \mathrm{m})$ estimated from the mean particle size distribution of the eroded soils and $W$ is the width of the terrain component (m), $\rho$ is the density of the particles $\left(\mathrm{g} \mathrm{m}^{-3}\right), g$ is the gravitational acceleration $\left(\mathrm{m} \mathrm{s}^{-2}\right)$, $q$ is the overland flow rate on a $1-\mathrm{m}$ strip $\left(\mathrm{m}^{3} \mathrm{~s}^{-1} \mathrm{~m}^{-1}\right)$ and $R$ is the flow depth $(\mathrm{cm})$.

(b) With the maximum value that is predicted by MUSLE assuming unrestricted erodibility with $K$ set to 0.5 :

$q_{\mathrm{s}}=E_{\mathrm{MUSLE}, K=0.5} \quad$ using Eq. (4)

Similar to the downslope partitioning scheme for surface runoff described by Güntner and Bronstert (2004), sediment that leaves a terrain component $i$ is partitioned into a fraction that is routed to the next terrain component downslope $\left(\mathrm{SED}_{\mathrm{in}, \mathrm{TC} i+1}\right)$ and a fraction that reaches the river directly $\left(\mathrm{SED}_{\text {river }, i}\right)$, representing the soil particles carried through preferential flow paths, such as rills and gullies. $\mathrm{SED}_{\text {river, } i}$ is a function of the areal fraction $\alpha_{i}$ of the current terrain $i$ component within the landscape unit according to:

$\mathrm{SED}_{\text {river }}, i=\mathrm{SY}_{i}\left(\alpha_{i} / \sum_{n=i}^{\mathrm{nTC}} \alpha_{n}\right)$

where $i$ is the index of the current terrain component (counted from top), $\alpha$ is the areal fraction of a terrain component and nTC is the number of terrain components in the current landscape unit.

\subsection{Transport and retention processes in the river module}

The river network consists of individual river stretches with pre-defined river cross-sections. Each stretch is associated with one sub-basin, i.e., each stretch receives the water and sediment fluxes from one sub-basin and the fluxes from the upstream river network. The water routing is based on the kinematic wave approximation after Muskingum (e.g. as described in Chow et al., 1988). Flow rate, velocity and flow depth are calculated for each river stretch and each time step using the Manning equation. A trapezoidal channel dimension with width $w(\mathrm{~m})$, depth $d(\mathrm{~m})$ and channel side ratio $r\left(\mathrm{~m} \mathrm{~m}^{-1}\right)$ is used to approximate the river cross-sections. If water level exceeds bankful depth, the flow is simulated across a pre-defined floodplain using a composite trapezoid with an upper width of $w_{\text {floodpl }}(\mathrm{m})$ and floodplain side ratio $r_{\text {floodpl }}\left(\mathrm{m} \mathrm{m}^{-1}\right)$. The WASA-SED river module contains routines for suspended and bedload transport using the transport capacity concept. The maximum suspended sediment concentration that can be transported in the flow is calculated using a power function of the peak flow velocity similar to the SWIM (Krysanova et al., 2000) and the SWAT model (Neitsch et al., 2002; Arnold et al., 1995):

$C_{\mathrm{s}, \max }=a \cdot v_{\text {peak }}^{b}$

where $v_{\text {peak }}(t)$ is the peak channel velocity $\left(\mathrm{m} \mathrm{s}^{-1}\right), C_{\mathrm{s}, \max }$ is the maximum sediment concentration for each river stretch in (ton $\mathrm{m}^{-3}$ ), and $a$ and $b$ are user-defined coefficients. If the actual sediment concentration $C_{\text {actual }}$ exceeds the maximum concentration, deposition occurs; otherwise degradation of the riverbed is calculated using an empirical function of a channel erodibility factor (Neitsch et al., 2002):

$$
\begin{aligned}
& \operatorname{RSED}_{\text {dep }}=\left(C_{\mathrm{s}, \text { max }} C_{\text {actual }}\right) \cdot V \\
& \operatorname{RSED}_{\text {ero }}=\left(C_{\mathrm{s}, \text { max }} C_{\text {actual }}\right) \cdot V \cdot K \cdot C
\end{aligned}
$$

where $\mathrm{RSED}_{\mathrm{dep}}$ (ton) is the amount of sediment deposited, $\mathrm{RSED}_{\text {ero }}$ (ton) the amount of sediment re-entrained in the reach segment (tons), $V$ is the Volume of water in the reach $\left(\mathrm{m}^{3}\right), K$ is the channel erodibility factor $\left(\mathrm{cm} \mathrm{h}^{-1} \mathrm{~Pa}^{-1}\right)$ and $C$ is the channel cover factor (-). Using the approach after Neitsch et al. (2002), it is possible to simulate the basic behaviour of a temporary storage and re-entrainment of sediments in individual river segments as a function of the transport capacity of the river.

For bedload transport, five transport formulae (MeyerPeter and Müller, 1948; Schoklitsch, 1950; Bagnold, 1956; Smart and Jaeggi, 1983; Rickenmann, 2001) are implemented for boundary conditions commonly found in upland meso-scale dryland catchments with small, gravel-bed streams as summarised in Table 1. For the calculation of bedload transport, near-equilibrium conditions are assumed, i.e. water and bedload discharge are thought to be steady at one time step. The bedload-transport implementation also assumes that no supply limitations occur, which appears feasible for low-magnitude flood events in headwater dryland catchments, where a large amount of sediments is thought to have been previously accumulated from an upstream, unregulated watershed. The bedload formulae consider both uniform and non-uniform sediments, grain sizes ranging from 0.4 to $29 \mathrm{~mm}$ or $D_{50}$ values larger $6 \mathrm{~mm}$ and river slopes ranging between 0.003 to $0.2 \mathrm{~m} \mathrm{~m}^{-1}$ (Table 1 ). 
Table 1. Bedload transport formulae in the river module.

\begin{tabular}{|c|c|}
\hline Formula & Range of conditions \\
\hline $\begin{array}{l}\text { 1. Meyer-Peter and Müller (1948) } \\
q_{\mathrm{s}}=\frac{8\left(\tau-\tau_{\text {crit }}\right)^{1.5}}{g \rho^{0.5}} 1000 \\
\text { with: } \tau=\rho g d S \text { and } \tau_{\text {crit }}=0.047\left(\rho_{\mathrm{s}}-\rho\right) g D_{m}\end{array}$ & $\begin{array}{l}\text { for both uniform and non-uniform } \\
\text { sediment, grain sizes ranging from } 0.4 \text { to } \\
29 \mathrm{~mm} \text { and river slopes of up to } 0.02 \mathrm{~m} \mathrm{~m}^{-1} \text {. }\end{array}$ \\
\hline $\begin{array}{l}\text { 2. Schoklitsch }(1950) \\
q_{\mathrm{s}}=2500 S^{1.5}\left(q-q_{\text {crit }}\right) 1000 \frac{\rho_{\mathrm{s}}-\rho}{\rho_{\mathrm{s}}} \\
\text { with: } q_{\text {crit }}=0.26\left(\frac{\rho_{\mathrm{s}}-\rho}{\rho}\right)^{\frac{5}{3}} \frac{D_{50}^{\frac{3}{2}}}{S^{\frac{7}{6}}}\end{array}$ & $\begin{array}{l}\text { for non-uniform sediment mixtures with } D_{50} \\
\text { values larger than } 6 \mathrm{~mm} \text { and riverbed slopes } \\
\text { varying between } 0.003 \text { and } 0.1 \mathrm{~m} \mathrm{~m}^{-1} \text {. }\end{array}$ \\
\hline $\begin{array}{l}\text { 3. Smart and Jaeggi (1983) } \\
q_{\mathrm{s}}=4.2 q S^{1.6}\left(1-\frac{\tau_{\text {crit }}^{*}}{\tau^{*}}\right) /\left(\frac{\rho_{\mathrm{s}}}{\rho}-1\right) 1000\left(\rho_{\mathrm{s}}-\rho\right) \\
\text { with: } \tau^{*}=\frac{d S}{\left(\frac{\rho_{\mathrm{s}}}{\rho}-1\right) D_{50}} \text { and } \tau_{\mathrm{crit}}^{*}=\frac{d_{\mathrm{crit}} S}{\left(\frac{\rho_{\mathrm{s}}}{\rho}-1\right) D_{50}}\end{array}$ & $\begin{array}{l}\text { for riverbed slopes varying between } \\
0.03-0.2 \mathrm{~m} \mathrm{~m}^{-1} \text { and } D_{50} \text { values } \\
\text { comparable to the ones of } \\
\text { the Meyer-Peter and Müller equation. }\end{array}$ \\
\hline $\begin{array}{l}\text { 4. Bagnold (1956) } \\
q_{\mathrm{s}}=4.25 \tau^{* 0.5}\left(\tau^{*}-\tau_{\text {crit }}^{*}\right)\left(\left(\frac{\rho_{\mathrm{s}}}{\rho}-1\right) g D_{50}^{3}\right)^{0.5} 1000\left(\rho_{\mathrm{s}}-\rho\right)\end{array}$ & $\begin{array}{l}\text { reshaped by Yalin (1977), applicable for sand } \\
\text { and fine gravel and moderate riverbed slopes. }\end{array}$ \\
\hline $\begin{array}{l}\text { 5. Rickenmann (2001) } \\
q_{\mathrm{s}}=3.1\left(\frac{D_{90}}{D 30}\right)^{0.2} \tau^{* 0.5}\left(\tau^{*}-\tau_{\mathrm{crit}}^{*}\right) \cdot F r^{1.1}\left(\frac{\rho_{\mathrm{s}}}{\rho}-1\right)^{-0.5}\left(\left(\frac{\rho_{\mathrm{s}}}{\rho}-1\right) g D_{50}^{3}\right)^{0.5} 1000\left(\rho_{\mathrm{s}}-\rho\right) \\
\text { with: } F r=\left(\frac{v}{g \cdot d}\right)^{0.5}\end{array}$ & $\begin{array}{l}\text { for gravel-bed rivers and torrents with bed } \\
\text { slopes between } 0.03 \text { and } 0.2 \mathrm{~m} \mathrm{~m}^{-1} \text { and } \\
\text { for } D_{50} \text { values comparable to the ones } \\
\text { of the Meyer-Peter and Müller equation in } \\
\text { the lower slope range with an average } D_{50} \\
\text { of } 10 \mathrm{~mm} \text { in the higher slope ranges. }\end{array}$ \\
\hline
\end{tabular}

$d$ : mean water flow depth $(\mathrm{m}), d_{\text {crit }}$ : critical flow depth for initiation of motion $(\mathrm{m}), D_{50}:$ median sediment particle size (m), $D_{30}:$ grainsizes at which $30 \%$ by weight of the sediment is finer $(\mathrm{m}), D_{90}$ : grain-sizes at which $90 \%$ by weight of the sediment is finer $(\mathrm{m}), D_{\mathrm{m}}$ : mean sediment particle size $(\mathrm{m}), \mathrm{Fr}$ : Froude number of the flow $(-), g$ : acceleration due to gravity $\left(\mathrm{m} \mathrm{s}^{-2}\right), q$ : unit water discharge $\left(\mathrm{m}^{2} \mathrm{~s}^{-1}\right)$, $q_{\text {crit }}$ : unit critical water discharge $\left(\mathrm{m}^{2} \mathrm{~s}^{-1}\right), q_{\mathrm{s}}$ : sediment discharge in submerged weight $\left(\mathrm{g} \mathrm{ms}^{-1}\right), S$ : slope $\left(\mathrm{m} \mathrm{m}^{-1}\right), v$ : water flow velocity $\left(\mathrm{m} \mathrm{s}^{-1}\right), \rho$ : fluid density $\left(1000 \mathrm{~kg} \mathrm{~m}^{-} 3\right), \rho_{\mathrm{s}}$ : sediment density $\left(2650 \mathrm{~kg} \mathrm{~m}^{-3}\right), \tau$ : local boundary shear stress $\left(\mathrm{kg} \mathrm{ms}^{-2}\right), \tau_{\text {crit }}:$ critical local boundary shear stress $\left(\mathrm{kg} \mathrm{ms}^{-2}\right), \tau^{*}$ : dimensionless local shear stress $(-), \tau_{\text {crit }}^{*}$ : dimensionless critical shear stress $(-)$.

\subsection{Retention processes in the reservoir module}

WASA-SED comprises a reservoir sedimentation module developed by Mamede (2008). It enables the calculation of the trapping efficiency of the reservoir, sediment deposition patterns and the simulation of several reservoir sediment management options and of reservoir life expectancy. The water balance and the bed elevation changes due to sediment deposition or entrainment are calculated for individual cross-sections along the longitudinal profile of the reservoir. Mamede (2008) subdivided the reservoir body (Fig. 2) in a river sub-reach component, where hydraulic calculations are based on the standard step method for a gradually varied flow (Graf and Altinakar, 1998) and a reservoir sub-reach component that uses a volume-based weighting factor approach adapted from the GSTARS model (Yang and Simoes, 2002). The transitional cross-section between the two spatial components is defined as where the maximum water depth for uniform river flow, computed with the Manning equation, is exceeded by the actual water depth of the cross-section due to the impoundment of the reservoir. Consequently, the length of the river sub-reach becomes longer for lower reservoir levels and vice versa. For the reservoir routing, the water discharge $Q_{j}$ of each cross-section $j$ is calculated as:

$$
Q_{j}=Q_{m}-\left(Q_{\text {in }}-Q_{\text {out }}\right) \sum_{k=m}^{j} v_{k} \text { with } v_{k}=V_{k} / V_{\text {res }}
$$

where $Q_{\text {in }}$ and $Q_{\text {out }}$ are reservoir inflow and outflow, $v_{k}$ is the fraction of reservoir volume represented by the crosssection, $V_{\text {res }}$ is the volume of the reservoir, $V_{k}$ is the volume represented by cross-section $k, m$ is the index for the first cross-section belonging to the reservoir sub-reach. Reservoir inflow considers the direct river runoff from the tributary rivers, direct rainfall and evaporation from the reservoir surface. 
Table 2. Sediment transport formulae in the reservoir module.

\begin{tabular}{|c|c|c|}
\hline Authors, range of sediments & Transport formula & Auxiliary equations \\
\hline \multirow{6}{*}{$\begin{array}{l}\text { Wu et al. (2000): } \\
0.004-100 \mathrm{~mm}\end{array}$} & $q_{\mathrm{b}, k}=P_{k} \phi_{\mathrm{b}, k} \sqrt{\Delta g d^{3}}$ & $\phi_{\mathrm{b}, k}=0.0053 \cdot\left[\left(\frac{n^{\prime}}{n}\right)^{3 / 2} \frac{\tau_{\mathrm{b}}}{\tau_{c, k}}\right]^{2.2}, n=R_{\mathrm{h}}^{2 / 3} S_{f}^{1 / 2} / v$ \\
\hline & & $n^{\prime}=\sqrt[6]{d_{50}} / 20, \quad \tau_{c, k}=\left(\gamma_{s}-\gamma\right) d_{k} \theta_{k} \xi_{k}$ \\
\hline & & $\zeta_{k}=\left(P_{\mathrm{e}, k} / P_{\mathrm{h}, k}\right)^{-0.6}, P_{\mathrm{e}, k}=\sum_{j=1}^{q} P_{\mathrm{b}, j} \cdot\left(d_{k} / d_{k}+d_{j}\right)$ \\
\hline & & $P_{\mathrm{h}, k}=\sum_{j=1}^{t} P_{\mathrm{b}, j} \cdot\left(d_{j} / d_{k}+d_{j}\right), \quad \tau_{\mathrm{b}}=\gamma R_{\mathrm{h}} S_{f}$ \\
\hline & $q_{\mathrm{s}, k}=P_{k} \phi_{\mathrm{s}, k} \sqrt{\Delta g d^{3}}$ & $\phi_{\mathrm{s}, k}=0.0000262 \cdot\left[\left(\frac{\tau}{\tau_{c, k}}-1\right) \cdot \frac{V}{\omega_{k}}\right]^{1.74}$ \\
\hline & & $\omega=\sqrt{13.95 \cdot\left(\frac{v}{d}\right)^{2}+1.09 \Delta g d}-13.95 \cdot\left(\frac{v}{d}\right)$ \\
\hline \multirow[t]{5}{*}{ Ashida and Michiue (1973): } & $q_{\mathrm{b}, k}=17 \cdot P_{k} u_{c, k} d_{k} \tau_{c, k}\left(1-\frac{\tau_{c, k}}{\tau_{k}}\right)\left(1-\sqrt{\frac{\tau_{c, k}}{\tau_{k}}}\right)$ & $\tau_{k}=\frac{u^{* 2}}{\Delta g d_{k}}, \quad u^{*}=\sqrt{g R_{\mathrm{h}} S_{f}}, \tau_{\mathrm{e}, k}=\frac{u_{\mathrm{e}, k}^{2}}{\Delta g d_{k}}$ \\
\hline & & $u_{\mathrm{e}, k}=\frac{V}{5.75 \log \left(\frac{R_{\mathrm{h}} / d_{50}}{1+2 \tau_{k}}\right)}, \quad \tau_{c, k}=\frac{u_{c, k}^{2}}{\Delta g d_{k}}$ \\
\hline & & $d_{k} / d_{50}<0.4: \quad u_{c, k}=\sqrt{0.85 \cdot u_{c, 50}}$ \\
\hline & & $\begin{array}{l}d_{k} / d_{50}>0.4: \quad u_{c, k}=\log 19 / \log \left(19 \cdot d_{k} / d_{50}\right) \cdot u_{c, 50} \\
u_{c, 50}=0.05 \cdot \Delta g d_{50}\end{array}$ \\
\hline & $q_{\mathrm{s}, k}=C \cdot V\left(e^{-p \cdot a}-e^{-p \cdot h}\right) \cdot \frac{e^{p \cdot a}}{p}$ & $\begin{array}{l}p=\frac{6 \cdot \omega_{k}}{0.412 \cdot u^{*} h}, \quad C=0.025 \cdot p_{k}\left(\frac{f\left(\varepsilon_{0}\right)}{\varepsilon_{0}}-F\left(\varepsilon_{0}\right)\right), \\
f\left(\varepsilon_{0}\right)=\frac{1}{\sqrt{2 \pi}} e^{\left(-0.5 \cdot \varepsilon_{0}^{2}\right)}, \quad F\left(\varepsilon_{0}\right)=\frac{1}{\sqrt{2 \pi}} \int_{\varepsilon_{0}}^{\infty} e^{\left(-0.5 \cdot \varepsilon_{0}^{2}\right)} d \varepsilon, \\
\varepsilon_{0}=\frac{\omega_{k}}{0.75 \cdot u^{*}}\end{array}$ \\
\hline IRTCES (1985): & $q_{\mathrm{t}}=\Omega \frac{Q^{1.6} S^{1.2}}{B^{0.6}}$ & $\begin{array}{l}\Omega=1600 \text { for loess sediment } \\
\Omega=650 \text { for } d_{50}<0.1 \mathrm{~mm} \\
\Omega=300 \text { for } d_{50}>0.1 \mathrm{~mm}\end{array}$ \\
\hline \multicolumn{3}{|l|}{$0.001-100 \mathrm{~mm}$} \\
\hline Ackers and White (1973): & $q_{\mathrm{t}}=P_{\mathrm{k}} \psi V d_{k}\left(\frac{V}{u^{*}}\right)^{n_{0}}\left(\frac{F_{\mathrm{gr}}}{F_{\mathrm{gr}, \mathrm{cr}} \xi_{\mathrm{k}}}-1\right)^{m_{o}}$ & $d_{k}^{*}=d_{k}\left(\Delta g / v^{2}\right)^{1 / 3} 1<d_{\mathrm{k}}^{*}<60: n_{o}=1-0.56 \cdot \log \left(d^{*}\right)$, \\
\hline $0.040-100 \mathrm{~mm}$ & & $m_{o}=\frac{9.66}{d^{*}}+1.34, \quad \psi=10^{-3.53+2.86 \cdot \log \left(d^{*}\right)-\log ^{2}\left(d^{*}\right)}$ \\
\hline & & $\begin{array}{l}F_{\mathrm{gr}, \mathrm{cr}}=\frac{0.23}{\sqrt{d^{*}}}-0.14 \text { for } d_{k}^{*}>60: n_{o}=0, m_{o}=1.5 \\
\psi=0.025, F_{\mathrm{gr}, \mathrm{cr}}=0.17\end{array}$ \\
\hline
\end{tabular}

$q_{\mathrm{b}, k}:$ transport rate of the $k$-th fraction of bedload per unit width, $q_{\mathrm{s}, k}$ : fractional transport rate of non-uniform suspended load, $k$ : grain size class, $P_{k}$ : ratio of material of size fraction $k$ available in the bed, $\Delta:$ relative density $(\gamma s / \gamma-1), \gamma$ and $\gamma_{\mathrm{s}}$ : specific weights of fluid and sediment, respectively; $g$ : gravitational acceleration; $d_{\mathrm{k}}$ : diameter of the particles in size class $\mathrm{k}, \phi_{\mathrm{b}, \mathrm{k}}$ : dimensionless transport parameter for fractional bed load yields, $v$ : kinematic viscosity, $\tau$ : shear stress of entire cross-section $\tau_{\mathrm{c}, k}$ : critical shear stress, $\theta_{\mathrm{c}}$ : critical Shields parameter, $\xi_{\mathrm{k}}$ : hiding and exposure factor, $P_{\mathrm{e}, k}$ and $P_{\mathrm{h}, k}$ : total exposed and hidden probabilities of the particles in size class $k, P_{\mathrm{b}, j}$ : probability of particles in size class $j$ staying in the front of particles in size class $k, \tau_{\mathrm{b}}$ : average bed shear stress; $n$ : manning's roughness, and $n^{\prime}$ : manning's roughness related to grains, $R_{\mathrm{h}}$ : hydraulic radius, $S_{f}$ : the energy slope, $V$ : average flow velocity, $d 50$ : median diameter, $\omega$ : settling velocity, $q_{\mathrm{t}}$ : total sediment transport capacity at current cross-section $\left(q_{\mathrm{t}}=q_{\mathrm{s}}+q_{\mathrm{b}}\right.$, for the equations after Wu et al., 2000; Ashida and Michiue, 1973), $S$ : bed slope, $B$ : channel width, $\Omega$ : constant as a function of grain size, $u^{*}$ : shear velocity, $u_{c, k}$ : effective shear velocity, $F_{\mathrm{gr}}$ : sediment mobility number, $n_{\mathrm{o}}, m_{\mathrm{O}}, \psi, F_{\mathrm{gr}, \mathrm{cr}}$ are dimensionless coefficients depending on the dimensionless particle size $d_{\mathrm{k}}^{*}$, $C$ : concentration at a reference level a.

The sediment transport is computed using a onedimensional equation of non-equilibrium transport of nonuniform sediment, adapted from Han and He (1990):

$\frac{d S}{d x}=\frac{\alpha \omega}{q}\left(S^{*}-S\right)$ where $S$ is the sediment concentration; $S^{*}$ is the sediment carrying capacity; $q$ is the discharge per unit width; $\omega$ is the settling velocity; and $\alpha$ is the coefficient of saturation recovery. According to Han and He (1990), the parameter $\alpha$ can be taken as 0.25 for reservoir sedimentation and 


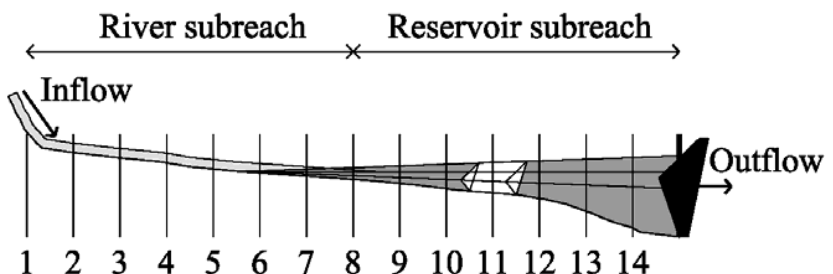

Fig. 2. Spatial discretisation of a reservoir along the longitudinal profile showing the river sub-reaches at cross-sections 1-7 and the main reservoir body at cross-sections 8-14. For each-cross-section, sediment deposition and re-entrainment is calculated for a control volume (as shown exemplarily for cross-section 11).

1.0 for scouring during flushing of a reservoir and in river channel with fine bed material. Mamede (2008) adapted four sediment transport equations (Wu et al., 2000; Ashida and Michiue, 1973; IRTCES, 1985; Ackers and White, 1973) for the calculation of the fractional sediment carrying capacity of both suspended sediments and bedload for different ranges of sediment particle sizes as given in Table 2 .

The bed elevation changes of the reservoir are computed for each cross-section taking into account three conceptual layers above the original bed material: a storage layer, where sediment is compacted and protected against erosion; an intermediate layer, where sediment can be deposited or resuspended; and the top layer, where sediment-laden flow occurs. The time-dependent mobile bed variation is calculated using the sediment balance equation proposed by Han (1980):

$\frac{\partial(Q S)}{\partial x}+\frac{\partial M}{\partial t}+\frac{\partial\left(\rho_{\mathrm{d}} A_{\mathrm{d}}\right)}{\partial t}=0$

where $Q$ is the water discharge; $S$ is the sediment concentration; $M$ is the sediment mass in the water column with unit length in longitudinal direction; $A_{\mathrm{d}}$ is the total area of deposition, and $\rho_{\mathrm{d}}$ is density of deposited material.

For each time step, the sediment balance is computed for each size fraction and cross-section, downstream along the longitudinal profile. The total amount of sediment deposited at each cross-section corresponds to the amount of sediment inflow exceeding the sediment transport capacity. On the other hand, the total amount of sediment eroded corresponds to the total amount of sediment that can still be transported by the water flux. Erosion is constrained by sediment availability at the bed of the reach. The geometry of the cross-section is updated whenever deposition or entrainment occurs at the intermediate layer. For each cross-section, the volume of sediments to be deposited is distributed over a stretch with a width of half the distance to the next upstream and downstream cross-section, respectively (Fig. 3a). Suspended sediment is assumed to be uniformly distributed across the crosssection and settles vertically, hence the bed elevation $e_{\mathrm{m}}$ at

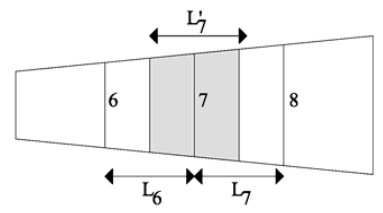

(a)

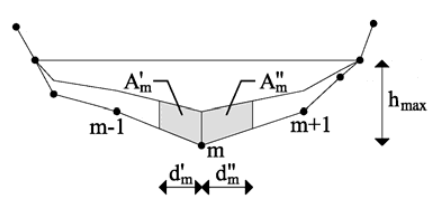

(b)
Fig. 3. Bed elevation change of a reservoir: (a) plan view along longitudinal profile: for each cross-section the volume of sediments to be deposited is distributed over a stretch $L_{7}^{\prime}$ with a width of half the distance to the next upstream (CS 6 with a width of $L_{6}$ ) and downstream (CS 8 with a width of $L_{8}$ ) cross-section, (b) deposition along an individual cross-section of the reservoir (for variables see Eq. 16).

a point $m$ along the cross-section changes proportionally to water depth:

$e_{\mathrm{m}}=e_{\mathrm{dep}} \cdot f_{\mathrm{d}, \mathrm{m}}$

where $e_{\mathrm{dep}}$ is the maximum bed elevation change at the deepest point of the cross-section caused by deposition and $f_{\mathrm{d}, \mathrm{m}}$ is a weighting factor which is computed as the ratio between water depth $h_{\mathrm{m}}$ at the point $\mathrm{m}$ and the maximum water depth $h_{\max }$ of the cross-section:

$f_{\mathrm{d}, \mathrm{m}}=h_{\mathrm{m}} / h_{\max }$

Figure $3 \mathrm{~b}$ shows schematically, how the sediment is distributed trapezoidally along the cross-section as a function of water depth $h_{\max }$, where $A_{\mathrm{m}}^{\prime}$ and $A_{\mathrm{m}}^{\prime \prime}$ are the sub-areas limited by the mean distances to the neighbour points $\left(d_{\mathrm{m}}^{\prime}\right.$ and $d_{\mathrm{m}}^{\prime \prime}$, respectively, starting from the deepest point of the cross-section profile), with $m$ running from 1 to $n_{\mathrm{w}}$ as the total number of demarcation points of the cross-section below water level.

Bed entrainment is distributed in an equivalent way by assuming a symmetrical distribution of bed thickness adapted from Foster and Lane (1983). The bed elevation change due to erosion is constrained by the maximum thickness of the intermediate layer. The bed elevation change $e_{\mathrm{m}}$ is given by:

$e_{\mathrm{m}}=e_{\mathrm{ero}} \cdot f_{\mathrm{e}, \mathrm{m}}$

where $e_{\mathrm{ero}}$ is the maximum bed elevation change at the deepest point of the cross-section caused by erosion and $f_{\mathrm{e}, \mathrm{m}}$ is a weighting factor given by Forster and Lane (1983):

$f_{\mathrm{e}, \mathrm{m}}=1-\left(1-X_{\mathrm{m}}\right)^{2.9}$

where $X_{\mathrm{m}}$ is a normalised distance along the submerged half perimeter given by:

$X_{\mathrm{m}}=X / X_{\max }$

where $X$ is the actual distance along the submerged half perimeter of the cross-section and $X_{\max }$ is the total wetted half perimeter between the cross-section point at the water surface and the deepest point of the cross-section. 
The implemented reservoir sedimentation routines allow the simulation of reservoir management options for the reduction or prevention of sedimentation (Mamede, 2008), such as annual flushing operation or partial drawdown of the reservoir water level. Both management operations result in a remobilisation of previously deposited sediments and the release of sediments out of the reservoir. The management options can then be used to calculate the life expectancy of the reservoir by taking into account potential scenarios of water and land management for different land-uses and erosion prevention schemes in the upslope catchments. Besides the above sediment routine for individual large reservoirs, WASA-SED optionally provides a module to represent water and sediment retention processes within networks of farm dams and small reservoirs that often exist in large numbers in dryland areas. These mini-reservoirs cannot be represented explicitly each of them in a large-scale model because of data and computational constraints. Instead, WASA-SED applies a cascade structure that groups the reservoirs into different size classes according to their storage capacity, defines water and sediment routing rules between the classes and calculates water and sediment balances for each reservoirs class. Details of the approach are presented with regard to water balance computations in Güntner et al. (2004) and for related sedimentation processes in Mamede (2008).

\subsection{Summary of model input and output data}

The model runs as a Fortran Console Application for catchment sizes of some tens to ten thousands of $\mathrm{km}^{2}$ on daily or hourly time steps. Climatic drivers are hourly or daily time series for precipitation, humidity, short-wave radiation and temperature. For model parameterisation, regional digital maps on soil associations, land-use and vegetation cover, a digital elevation model with a cell size of $100 \mathrm{~m}$ (or smaller) and, optionally, data on reservoir geometry are required. The soil, vegetation and terrain maps are processed with the LUMP tool (see above) to derive the spatial discretisation into soil-vegetation units, terrain components and landscape units. Table 3 summarises the input parameters for the climatic drivers and the hillslope, river and reservoir modules. The vegetation parameters may be derived from the comprehensive study of, for example, Breuer et al. (2003), the soil and erosion parameters with the data compilations of, e.g., FAO (1993, 2001), Morgan (1995), Maidment (1993) and Schaap et al. (2001), or from area-specific data sources.

The model output data are time series with daily or hourly time steps for lateral and vertical water and sediment fluxes from the sub-basins, the water and sediment discharge in the river network and the bed elevation change due to sedimentation in the reservoir as summarised in Table 4. A user's manual for model parameterisation, the current version of LUMP and the source-code of WASA-SED as well as related tools can be used freely under the BSD-license, to be down-

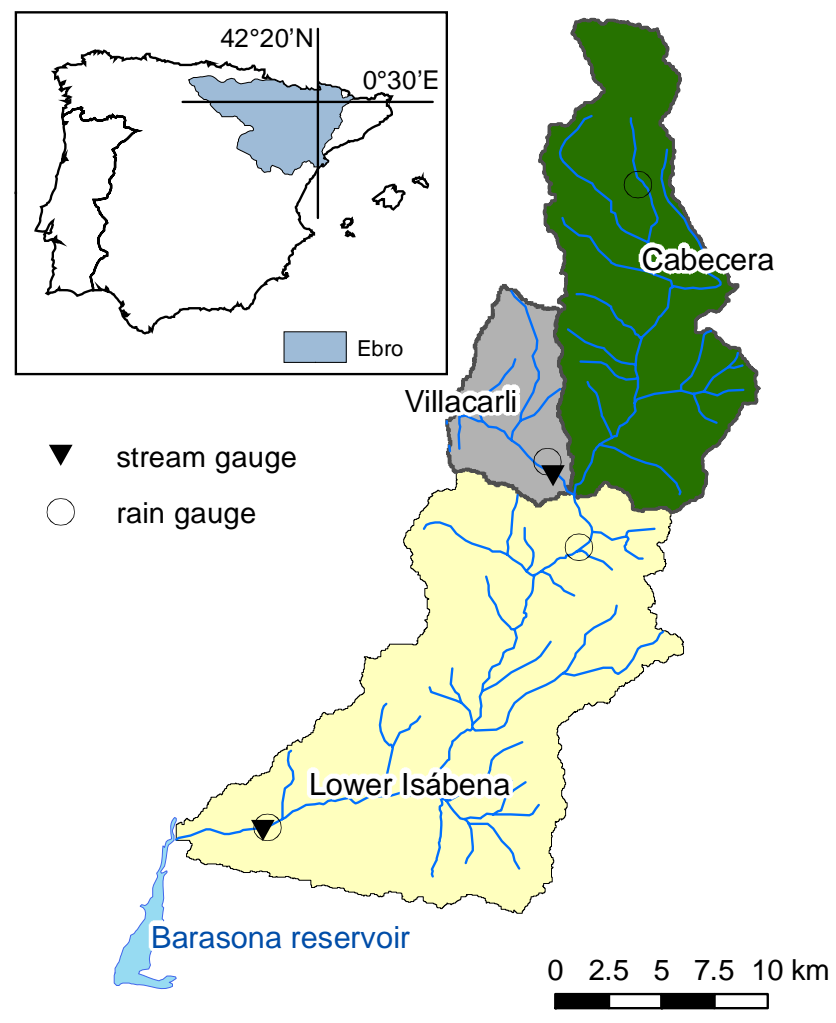

Fig. 4. Isábena catchment and its sub-catchments.

loaded from http://brandenburg.geoecology.uni-potsdam.de/ projekte/sesam/reports.php.

\section{Example application: modelling badland erosion, transient riverbed storage and reservoir sedimentation for the Isábena catchment}

\subsection{Study area and modelling objectives}

The Isábena catchment $\left(445 \mathrm{~km}^{2}\right)$ is located in the Central Spanish Pre-Pyrenees $\left(42^{\circ} 11^{\prime} \mathrm{N}, 0^{\circ} 20^{\prime} \mathrm{E}\right)$. Climate is a typical Mediterranean mountainous type with mean annual precipitation rates around $770 \mathrm{~mm}$. Heterogenous relief, lithology (Paleogene, Cretaceous, Triassic, Quaternary) and landuse (agriculture in the valley bottoms, mattoral, woodland and pasture in the higher parts) create a diverse landscape. Hotspot erosion occurs on badlands in the upper middle of the catchment, which is dominated by Mesozoic carbonate rocks and marls (Fig. 4). The Isábena river never dries up, although flows are low during the summer (minimum flow: $0.45 \mathrm{~m}^{3} \mathrm{~s}^{-1}$, mean annual discharge: $Q_{90}=6.1 \mathrm{~m}^{3} \mathrm{~s}^{-1}$, $Q_{\mathrm{MC}}=25.3 \mathrm{~m}^{3} \mathrm{~s}^{-1}, \quad Q_{\mathrm{C}}=318.3 \mathrm{~m}^{3} \mathrm{~s}^{-1}$, CHEBRO, 2002). The Isábena River disembogues into the Ésera River (catchment area: $906 \mathrm{~km}^{2}$ ), which then flows into the Barasona Reservoir (built mainly for irrigation purposes). The Barasona Reservoir is heavily affected by the sedimentation 
Table 3. Input data requirements for WASA-SED.

\begin{tabular}{|c|c|}
\hline Type & Model input parameter \\
\hline Climate & $\begin{array}{l}\text { Daily or hourly time series on rainfall }\left(\mathrm{mm} \mathrm{day}^{-1}, \mathrm{~mm} \mathrm{~h}^{-1}\right) \\
\text { Daily time series for average short-wave radiation }\left(\mathrm{W} \mathrm{m}^{-2}\right) \\
\text { Daily time series for humidity }(\%) \\
\text { Daily time series for temperature }\left({ }^{\circ} \mathrm{C}\right)\end{array}$ \\
\hline Vegetation & $\begin{array}{l}\text { Stomata resistance }\left(\mathrm{s} \mathrm{m}^{-1}\right) \\
\text { Minimum suction }(\mathrm{hPa}) \\
\text { Maximum suction }(\mathrm{hPa}) \\
\text { Height }(\mathrm{m}) \\
\text { Root depth }(\mathrm{m}) \\
\text { LAI }(-) \\
\text { Albedo }(-)\end{array}$ \\
\hline \multicolumn{2}{|l|}{ USLE C (-) } \\
\hline Soil & $\begin{array}{l}\text { No. of horizons }{ }^{\mathrm{a}} \\
\text { Residual water content (Vol. \%) } \\
\text { Water content at permanent wilting point (Vol. \%) } \\
\text { Usable field capacity (Vol. \%) } \\
\text { Saturated water content (Vol. \%) } \\
\text { Saturated hydraulic conductivity }\left(\mathrm{mm} \mathrm{h}^{-1}\right) \\
\text { Thickness (mm) } \\
\text { Suction at wetting front }(\mathrm{mm}) \\
\text { Pore size index }(-) \\
\text { Bubble pressure }(\mathrm{cm}) \\
\text { USLE K }(-) \\
\text { Particle size distribution }\end{array}$ \\
\hline Soil vegetation component & $\begin{array}{l}\text { Manning's n [-] } \\
\text { USLE P [-] }\end{array}$ \\
\hline Terrain and river & $\begin{array}{l}\text { Hydraulic conductivity of bedrock }\left(\mathrm{mm} \mathrm{d}^{-1}\right) \\
\text { Mean maximum depth of soil zone (mm) } \\
\text { Depth of river bed below terrain component }(\mathrm{mm}) \\
\text { Storage coefficient for groundwater outflow (day) } \\
\text { Bankful depth of river }(\mathrm{m}) \\
\text { Bankful width of river }(\mathrm{m}) \\
\text { Run to rise ratio of river }(-) \\
\text { Bottom width of floodplain }(\mathrm{m}) \\
\text { Run to rise ratio of floodplain side slopes }(-) \\
\text { River length }(\mathrm{km}) \\
\left.\text { River slope (m m }{ }^{-1}\right) \\
D_{50} \text { (median sediment particle size) of riverbed (m) } \\
\text { Manning's n for riverbed and floodplains }(-)\end{array}$ \\
\hline Reservoir & $\begin{array}{l}\text { Longitudinal profile of reservoir }(\mathrm{m}) \\
\text { Cross-section profiles of reservoir }(\mathrm{m}) \\
\text { Stage-volume curves } \\
\text { Initial water storage and storage capacity volumes }\left(\mathrm{m}^{3}\right) \\
\text { Initial area of the reservoir (ha) } \\
\text { Maximal outflow through the bottom outlets }\left(\mathrm{m}^{3} \mathrm{~s}^{-1}\right) \\
\text { Manning's roughness for reservoir bed } \\
\text { Depth of active layer (m) } \\
\text { Spillway coefficients } \\
\text { Dry bulk densities of deposits }\end{array}$ \\
\hline
\end{tabular}

${ }^{\mathrm{a}}$ for each soil horizon, all following parameters in the column are required; ${ }^{\mathrm{b}}$ of topmost horizon. 
Table 4. Model output files of WASA-SED.

\begin{tabular}{ll}
\hline Spatial unit & Output (daily time series) \\
\hline Sub-basins & $\begin{array}{l}\text { potential evapotranspiration }\left(\mathrm{mm} \mathrm{day}^{-1}\right) \text { actual evapotranspiration }\left(\mathrm{mm} \mathrm{day}^{-1}\right) \text { overland flow }\left(\mathrm{m}^{3} \text { timestep }\right. \\
\text { sub-surface flow } \\
\left(\mathrm{m}^{3} \text { timestep }\right.\end{array}$ \\
& $\begin{array}{l}\text { in the soil profile }(\mathrm{mm}) \\
\text { water discharge }\left(\mathrm{m}^{3} \mathrm{~s}^{-1}\right) \text { suspended sediment concentration }\left(\mathrm{g} \mathrm{l}^{-1}\right) \text { bedload rate as submerged weight }\left(\mathrm{kg} \mathrm{s}^{-1}\right)\end{array}$ \\
River & $\begin{array}{l}\text { sediment outflow from the reservoir }(\mathrm{t} \text { timestep } \\
\text { Reservoir }) \text { bed elevation change due to deposition or erosion }(\mathrm{m}) \text { storage } \\
\text { capacity and sediment volume } \\
\text { changes }\left(\mathrm{hm}^{3}\right) \text { life expectancy (years) effluent size distribution of sediment }(-)\end{array}$ \\
\hline
\end{tabular}

Table 5. Geospatial data sources for Isbena case study.

\begin{tabular}{llll}
\hline Layer & Source & Author & Resolution \\
\hline Topography & DEM generated from ASTER and SRTM data using stereo-correlation & SESAM (unpublished) & $30 \mathrm{~m}$ \\
Soils & Mapa de suelos (Clasificacion USDA, 1987) & CSIC/IRNAS (2000) & $1: 1000000$ \\
Lithology & Geología Dominio SINCLINAL DE TREMP; mapa "Fondos Aluviales"” & CHEBRO (1993) & $1: 50000 / 200000$ \\
Land use & Usos de Suelos (1984/1991/1995) de la cuenca hidrográfica del Ebro & CHEBRO (1998) & $1: 100000$ \\
Badlands & Digitized from high-resolution airphotos & SESAM (unpublished) $1: 5000$ \\
River stretches & Field survey & SESAM (unpublished) & - \\
\hline
\end{tabular}

of suspended sediments that reach the reservoir via the Ésera and Isábena River. The badlands are considered to be the major cause for the sedimentation of the Barasona Reservoir (Valéro-Garces et al., 1999; Francke et al., 2008) whose initial capacity of $92 \mathrm{hm}^{3}$ has been considerably reduced by the subsequent siltation over the last several decades, thus threatening the mid-term reliability of irrigation water supply (Mamede, 2008).

The WASA-SED model was used to simulate water and sediment fluxes from the hillslopes and suspended sediment transport in the river. Reservoir sedimentation dynamics were simulated separately with WASA-SED's reservoir module. The simulation results were compared to discharge and suspended sediment concentration data at the catchment outlet and a headwater catchment containing large areas of badland formations (for details see Francke et al., 2008). Table 5 provides an overview of the data-sources used in the parameterisation (for details, see Mamede, 2008; Francke, 2009).

With the highly heterogeneous landscape of the study area, modest data situation and the intense sediment export dynamics caused by the badlands, the catchment poses a great challenge for any modelling. We propose that an adequate performance of the WASA-SED model in these settings is a strong indicator for its general applicability. On the other hand, the shortcomings of the model will become apparent. The model was employed to assess crucial questions for land and water management: a) how large is the runoff and sedi- ment export from badland headwater catchments and the entire Isábena catchment, b) is there any transient times or temporary storage of sediments being delivered from the badlands to the outlet of the meso-scale catchment in the river system of the Isábena, and c) what is the life expectancy of the Barasona reservoir under different management options.

High-resolution time series for water and sediment fluxes (1-10 min resolution) were available for a limited time period of one year at the outlets of the badland headwater Villacarli $\left(41 \mathrm{~km}^{2}\right)$ and the entire Isábena catchment. Several bathymetric surveys of the Barasona reservoir enabled a validation of sedimentation rates along the longitudinal reservoir profile and for individual cross-sections.

\subsection{Modelling runoff and erosion from highly erodible badlands and sediment fluxes at the catchment outlet of the Isábena catchment}

WASA-SED was applied to the Isábena catchment and its badland headwater catchment Villacarli. Previous studies revealed the hotspot erosion dynamics of Villacarli. It was shown that suspended sediment concentration in the Villacarli tributary and in the main stem of the Isabena catchment frequently exceeded $30 \mathrm{gl}^{-1}$, with maximum rates of up to $277 \mathrm{~g} \mathrm{l}^{-1}$ due to the accelerated rate of erosion from the badland areas (Francke et al., 2008; López-Tarazón et al., 2009). Due to the prevailing highly dynamic runoff characteristics and intense sediment transport dynamics, both 
Table 6. Summary of model performance of the Isábena.

\begin{tabular}{|c|c|c|c|c|}
\hline \multirow{3}{*}{$\begin{array}{l}\text { Subcatchment } \\
\text { (modelled timespan) }\end{array}$} & \multirow{3}{*}{$\begin{array}{l}\text { Hydrological } \\
\text { model } \\
\text { NS }(\%)\end{array}$} & \multicolumn{3}{|c|}{ Sediment model } \\
\hline & & \multicolumn{2}{|c|}{$\mathrm{SY}(\mathrm{t})$} & \multirow[t]{2}{*}{$e_{\mathrm{SY}}(\%)$} \\
\hline & & Observed & modelled & \\
\hline $\begin{array}{l}\text { Villacarli } \\
\text { (11 Sep 2006-30 Apr 2007) }\end{array}$ & 0.70 & kern5.5mm74000 & kern5.5mm66000 & -11 \\
\hline $\begin{array}{l}\text { Lower Isábena } \\
\text { (15 Sep 2006-29 Jan 2007) }\end{array}$ & 0.84 & 119000 & 211000 & 77 \\
\hline
\end{tabular}

NS: Nash-Sutcliffe (1970) coefficient of efficiency; SY: sediment yield; $e_{\mathrm{SY}}$ : relative error in modelled compared to observed sediment yield.

monitoring and modelling these fluxes is especially challenging. The testing data sets were obtained during extensive fieldwork as described in Francke et al. (2008) which defines the modelled time span (September 2006January/April 2007).

The hydrological module of WASA-SED was able to reproduce the daily runoff dynamics of storm events for both the Villacarli badlands and the entire Isábena catchment (Fig. 5) and yields Nash-Sutcliffe (1970) coefficients of efficiency of 0.7 and 0.84 , respectively (Table 6). The most pronounced deficit of the hydrological module was its failure in correctly reproducing runoff peaks for certain events, which can be attributed to insufficient coverage of the spatial variation of rain storm events and unrepresented hydrological processes such as snowmelt. Furthermore, the temporal resolution of one day, which can only partly capture the effects of high-intensity rainfall and restricts the reliability of the hydraulic computations, poses a limitation to model performance. The representation of low flow following a larger runoff event is affected by the simple modelling approach for groundwater in WASA-SED and the role of transmission losses, which could only rudimentarily be included in the parameterization (Fig. 5).

For the sediment model, it was shown that the concept of combining runoff-driven erosion equations (Eqs. 4 and 5) and a transport capacity limitation (Eq. 6) yielded the best model performance, with only $11 \%$ underestimation in sediment yield (compared to observations, see Table 6) even for the badland-catchment Villacarli. WASA-SED reasonably reproduced the total sediment yield of individual flood events (Fig. 6, note the logarithmic scale) that occurred after high-intensity rainstorm events in the autumn season. These events usually last one to three days and are responsible for the major part of sediments being transported through the river system. Figure 6 also illustrates that the observed sediment fluxes during low flow periods - a particularity of the Isábena basin - were still underestimated for the badland headwater catchment, however well reproduced for the lower Isábena catchment.
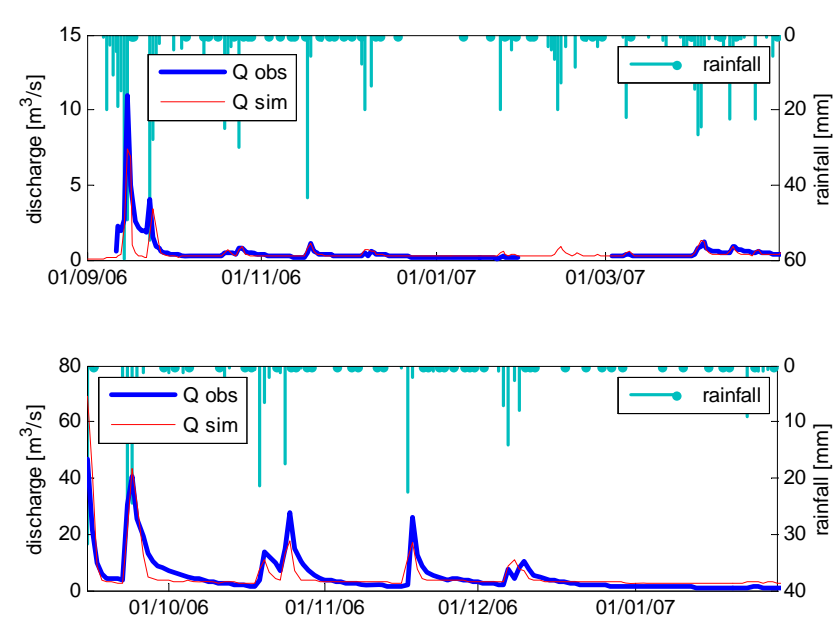

Fig. 5. River discharge ( $Q_{\mathrm{obs}}$ : observed vs. $Q_{\text {sim }}$ : simulated) for the Villacarli badlands (11 September 2006-30 April 2007, top) and the Isábena (15 September 2006-29 January 2007, bottom) catchment.

\subsection{Modelling the transient sediment storage in the lower Isábena River}

Figure 7 displays the temporal variation of the simulated sediment storage, i.e. sediments which were deposited during a runoff and erosion storm event and were stored in the riverbed of the lower section of the Isábena catchment (Fig. 4) with a length of about $33 \mathrm{~km}$ for September 2006January 2007.

The model results suggest that the sediment storage exhibits a very dynamic behaviour. Large sediment masses of up to several 1000 up to 100000 tons (with a simulated peak value of $23690 \mathrm{tday}^{-1}$ on 15 Setember 2006) were removed out of the riverbed in short time periods of days or weeks. The model results substantiate previous hypotheses that a major amount of the sediments originating from the badlands are stored in a transient river storage for several days to weeks (Mueller et al., 2006; López-Tarazón et al., 2009) and are re-entrained and transported out of the 

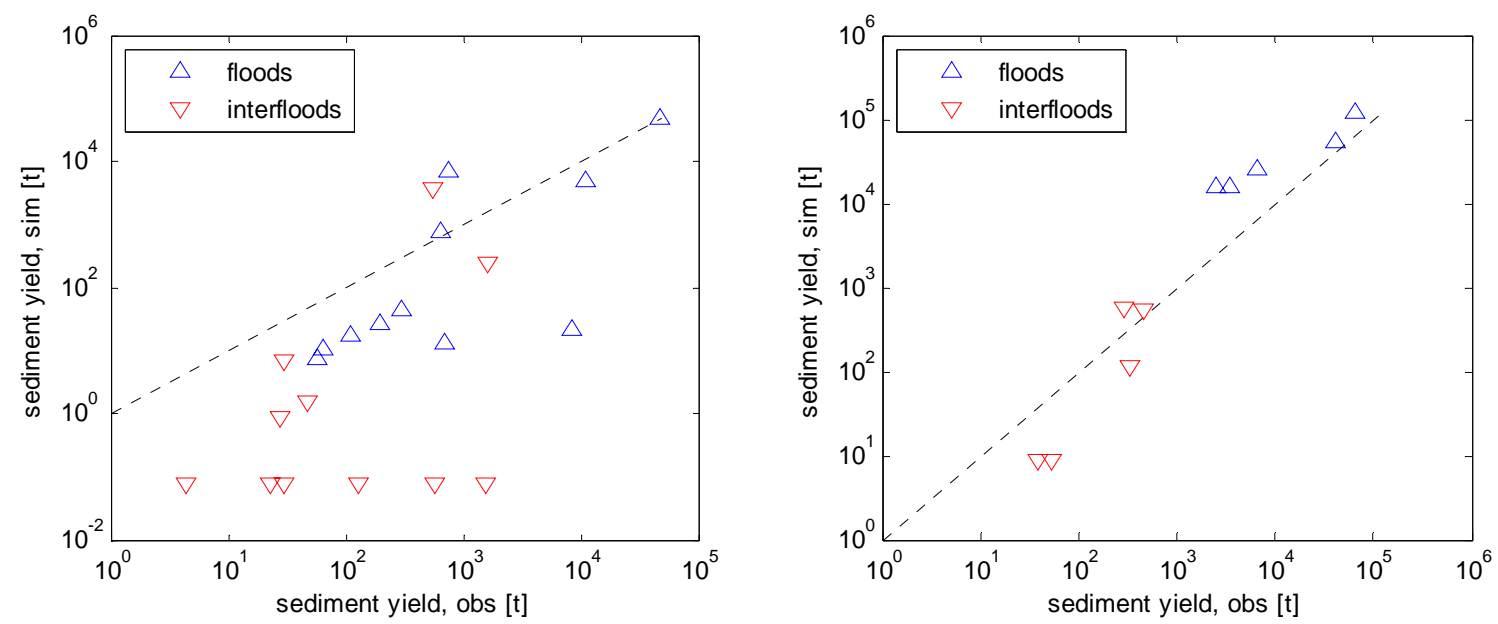

Fig. 6. Flood-based sediment yield (observed vs. modelled) for the Villacarli (11 September 2006-4 January 2007, right) badlands and the Isábena catchment (15 September 2006-29 January 2007, left).

Table 7. Comparison of observed and modelled transient riverbed storage data with sediment fluxes of the Isabena and Villacarli catchments.

\begin{tabular}{llc}
\hline Landscape compartment & Transport or storage process & Mass (t) \\
\hline \multirow{2}{*}{ Villacarli badland headwater } & Suspended sediments: Sep 2006 & 68150 \\
& Suspended sediments: 13 Sep 2006 & 47447 \\
& Suspended sediments: 22 Sep 2006 & 11019 \\
Riverbed & Storage: Sep 2006 & 53180 \\
& Modelled storage 15 Sep 2006 & 23690 \\
& Suspended sediment: Sep 2006 & 162450 \\
Isabena catchment & Suspended sediment: 13 Sep 2006 & 86430 \\
& Suspended sediment: 22 Sep 2006 & 45770 \\
\hline
\end{tabular}

a derived from Francke et al. (2008) by taking their daily/monthly sediment flux values for a specific badland

$\mathrm{b}$ linear interpolation of field data by Mueller (2008)

c derived from WASA-SED model, Fig. 7

d from Lopez-Tarazon et al. (2009), annual average: May 2005-May 2006: 90410 t, May 2006-May 2007: 250290 t, May 2007-May 2008: $212070 \mathrm{t}$

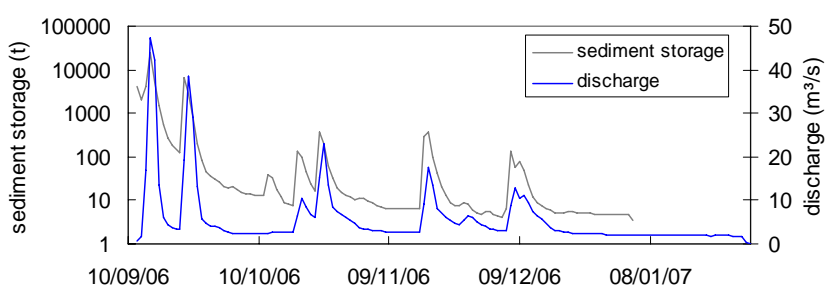

Fig. 7. Modelled discharge and sediment storage in the riverbed of the Lower Isábena catchment (15 September 2006-29 January 2007).

catchment by subsequent storm events which often are much smaller than the storms which had caused the erosion in the badland area. A field study was carried out to quantify the transient riverbed storage of fine sediments of the Lower Isábena River during the autumn period (first two weeks of
September 2006) when most of the sediment transfer in the Isabena catchment takes place (Mueller, 2008). For 78 crosssections along a $33 \mathrm{~km}$ river stretch, the heights of accumulated fine sediments (mainly silty clay) on the buried armour layer were measured with a graduated stainless steel rod with a sampling interval of twenty centimetres across the bankful width of the river (40-250 height measurement per crosssection as a function of river width). Fine-sediment depth was determined by probing with the rod until a change in resistance was felt as it struck coarser material. The riverbed storage of sediments averages at $67 \mathrm{~kg} \mathrm{~m}^{-2}$ (with a range of $6-527 \mathrm{~kg} \mathrm{~m}^{-2}$ ), substantially higher than the figures normally presented in recent literature (averages between 0.2 and $2.4 \mathrm{~kg} \mathrm{~m}^{-2}$ ). A linear interpolation of the field data yielded total riverbed storage of 53180 tons for September 2006. 


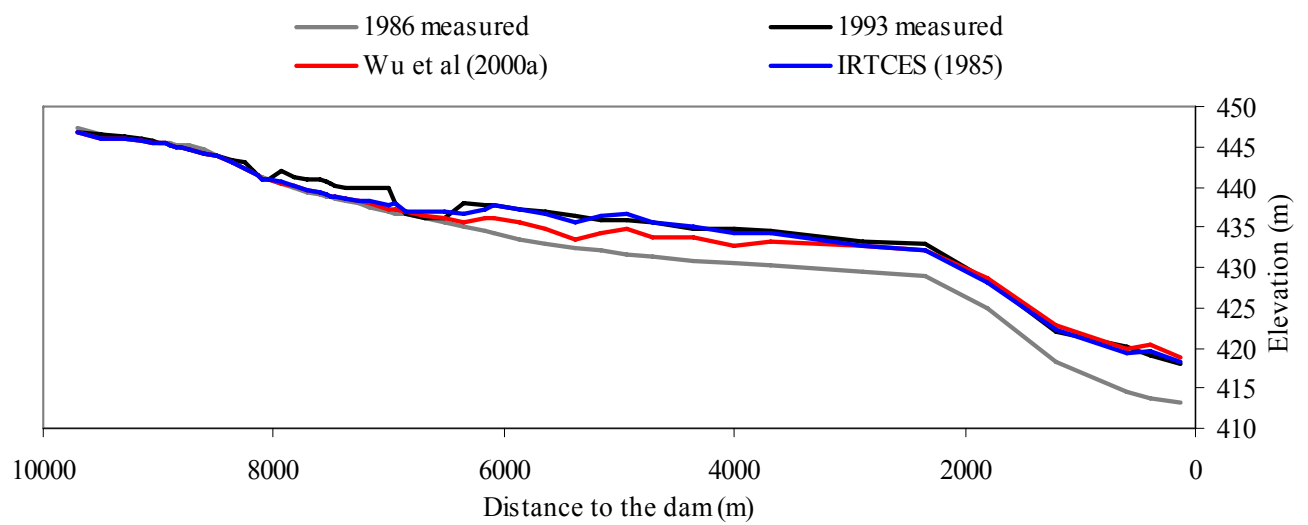

Cross Section 40

Cross Section 59
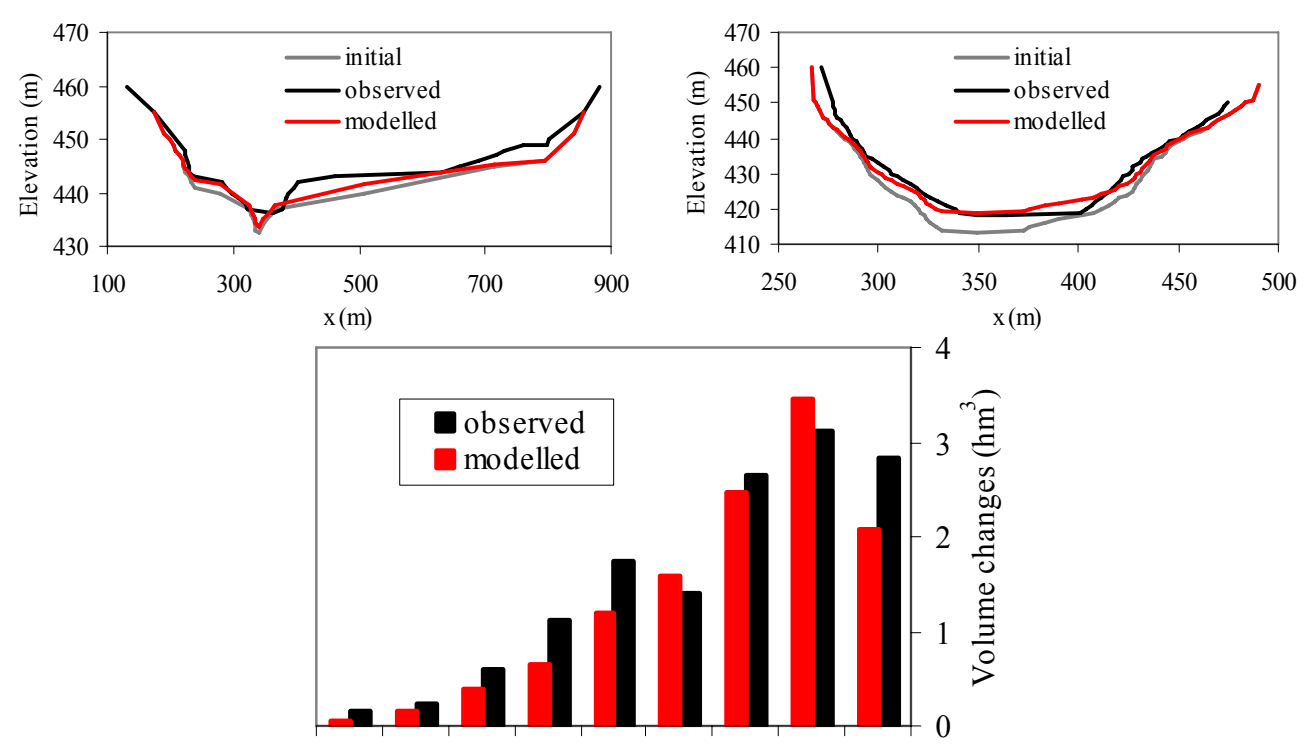

9-8 $\quad 8-7 \quad 7-6 \quad 6-5 \quad 5-4 \quad 4-3 \quad 3-2 \quad 2-1 \quad 1-0$

Distance to the dam $(\mathrm{km})$

Fig. 8. Measured and simulated bed elevation changes for the simulation period 1986-1993 (a) along the longitudinal profile of the Barasona Reservoir for the Wu et al. (2000) and Tsinghua University (IRTCES, 1985) formulas; (b) at two different cross-sections for the Wu et al. (2000) formula; (c) Sediment volume changes along the longitudinal profile of the reservoir.

Table 8. Simulated life expectancy of the Barasona reservoir for four different management options.

\begin{tabular}{llll}
\hline $\begin{array}{l}\text { Management } \\
\text { scenario }\end{array}$ & Type & $\begin{array}{l}\text { Sedimentation rate } \\
\left(10^{6} \mathrm{~m}^{3} \mathrm{year}^{-1}\right)\end{array}$ & $\begin{array}{l}\text { Expected life } \\
\text { time (years) }\end{array}$ \\
\hline 1 & $\begin{array}{l}\text { no sediment management, bottom outlet remains closed } \\
\text { flushing operation: seasonal emptying after irrigation period } \\
\text { when floodevents usually occur }\end{array}$ & $\begin{array}{l}1.95 \\
(-1.30)^{\mathrm{a}}\end{array}$ & - \\
3 & $\begin{array}{l}\text { partial draw-down after irrigation period (constant level of } \\
\text { 430 ma.s.l.) } \\
\text { partial draw-down after irrigation period (constant level of } \\
\text { 430 ma.s.l.) }\end{array}$ & 64 \\
4 & & 80 \\
\hline
\end{tabular}

a storage capacity increased due to flushing operations. 
Table 9. Summary of current WASA-SED model applications.

\begin{tabular}{|c|c|c|c|}
\hline Processes & Location & Spatial scale & Authors \\
\hline $\begin{array}{l}\text { Connectivity investigation of sediment genera- } \\
\text { tion and transport for a semi-arid catchment }\end{array}$ & Bengue, Brazil & $933 \mathrm{~km}^{2}$ & Medeiros et al. (2010) \\
\hline Erosion of individual badland hillslopes & Aragon, Spain & ca. 10 ha & Appel (2006) \\
\hline $\begin{array}{l}\text { Sedimentation and management options for the } \\
\text { Barasona reservoir }\end{array}$ & Aragon, Spain & $1340 \mathrm{~km}^{2}$ & Mamede (2008) \\
\hline $\begin{array}{l}\text { Sediment transport in a network of multiple } \\
\text { small reservoirs }\end{array}$ & Bengue, Brazil & $933 \mathrm{~km}^{2}$ & Mamede (2008) \\
\hline $\begin{array}{l}\text { Surface runoff, river discharge and water avail- } \\
\text { ability in reservoir networks }\end{array}$ & Ceará, Brazil & Up to several $10000 \mathrm{~km}^{2}$ & $\begin{array}{l}\text { Güntner and Bronstert (2004), } \\
\text { Güntner et al. (2004) }\end{array}$ \\
\hline
\end{tabular}

Comparing the order of magnitude of measured stored sediments in September 2006 (53 180 t for a river stretch of $33 \mathrm{~km}$ ) with individual, monthly and annual sediment fluxes measured from the Villacarli and at the Isábena outlets, the field data and the modelling results confirm that the riverbed storage can act as a sediment source for individual flood events as much as the hillslopes (Table 7 comparing the measured suspended sediments for September 2006 and two individual events at the outlet of both catchments with the measured and simulated transient storage in the riverbed). To ensure a sustainable river basin management, it is important to evaluate the relative importance of all involved sediment transport and storage compartments of a meso-scale catchment. This model application stresses the relative importance of the transient riverbed storage which was previously underrated for meso-scale sediment budgets of dryland catchments. At the moment it is possible to compare the modelled transient storage with one observation in time only (it took two weeks to collect the data set for the entire storage). More spatial and temporal variable field data on riverbed storage are required to enable an in-depth validation of its transfer behaviour.

\subsection{Modelling sedimentation and management options for the Barasona reservoir}

Mamede (2008) applied the reservoir module of the WASASED model to the Barasona Reservoir (location in Fig. 4) with a maximal storage capacity of $93 \mathrm{hm}^{3}$ and a length of about $10 \mathrm{~km}$ using a total number of 53 cross-sections. Detailed bathymetric surveys were available for five years (1986, 1993, 1998, 2006, and 2007). They enable the parameterisation of the cross-sections and the evaluation of bed elevation change over time and space.

The reservoir module was able to reproduce annual bed elevation changes due to sedimentation of high-concentration inflow both along the longitudinal profile and for individual cross-sections of the reservoir (Fig. 8a showing the longitudinal profile corresponding to the entire length of the Barasona Reservoir in Fig. 4, Fig. 8b showing the elevation changes for the time period 1986-1993). Figure 8c gives a quantitative comparison of measured and simulated sediment volume changes in a cumulative form (for $1 \mathrm{~km}$ segments). Overall, model deviations were less than $15 \%$. However, considerable differences occurred close to the reservoir inlet which may be explained by singularities of the reservoir topology (lateral constrictions and sharp bend of the narrow channel). A sensitivity analysis by Mamede (2008) showed that the WASA-SED reservoir module was sensitive to the choice of sediment transport equations (Fig. 8a shows that the IRTCES equation works slightly better than the Wu equation) and the number of cross-sections used. A coarser model discretization with, e.g., 14 instead of 53 cross-sections, slightly decreased model performance, although not significantly.

The WASA-SED model was then applied to estimate life expectancies of the Barasona Reservoir under different sediment management options (Table 8). Without any sediment management (scenario 1), the model suggests that the reservoir is filled with sediments from the catchment area after 47 years. If a partial draw-down of the reservoir water level to a specific water level is used to flush out sediments after the irrigation period, life time can be extended to 64-80 years (scenarios 3 and 4). Model results suggest that management scenario 2 is the most efficient option as it not only prevents sedimentation of the reservoir but it also leads to a remobilisation and release of deposited sediments from the reservoir bed by flushing them out of the bottom outlet during flood events (Table 4) and thus preserving the original storage capacity. 


\section{Merits and limits of the WASA-SED model}

The WASA-SED model is a new modelling framework for the qualitative and quantitative assessment of sediment transfer in large dryland catchments. The assets of the model are threefold:

First, the spatially detailed representation and scaling of catena characteristics using the landscape unit approach enables an effective way of parameterising large areas without averaging out topographic details that are particularly relevant for sediment transport. Crucial spatial information for the various sections of the catena, e.g., slope gradients, is preserved. The semi-distributed approach of WASA-SED model therefore tends to be more adequate than raster-based erosion models at the meso-scale which for large cell sizes normally lack satisfactory aggregation methods for representing topographic information when large cell sizes are employed to represent the often highly heterogeneous catenas of dryland catchments. Thus, simulated overland flow dynamics allow a realistic calculation of transport capacities and deposition patterns along the catena in WASA-SED.

Secondly, the WASA-SED framework allows a coherent handling of spatial input data in combination with the semiautomated discretisation tool LUMP (Francke et al., 2008). The tool provides an objective and easily reproducible delineation of homogeneous terrain components along a catena and consequently an upscaling rationale of small-scale hillslope properties into the regional landscape units.

Thirdly, the WASA-SED model includes an integrative representation of various sediment processes in terms of hillslope and river retention and transport, and of reservoir sedimentation. Thus, different but closely interconnected sediment transport and storage dynamics can be assessed at the river basin scale, including the effect of sediment management options both at hillslopes and in the river network. At the same time, the model maintains a slim demand in computational power and storage and is efficient enough to cope with data handling required for large catchments.

The source-code of WASA-SED can be used freely under the BSD-license, to be downloaded from http://brandenburg. geoecology.uni-potsdam.de/projekte/sesam//reports.php.

The example application for the Isábena catchment has given quality measures for a range of modules of WASASED. The model was able to reproduce the runoff and erosion dynamics of a badland headwater catchment, gave new insight into the importance of a transient sediment storage of the lower riverbed, and quantified reservoir sedimentation by calculating the spatial and temporal bed elevation changes along a large reservoir. The Isábena application revealed difficulties in reproducing the recession phase of the hydrographs and sedigraphs after storm events for the badland headwater catchment and at the outlet of the Isábena catchment, which is due to a simplified modelling approach for transmission losses and groundwater processes. The validation of the simulated transient sediment storage in the riverbed remains difficult, as no appropriate validation data are available for this process in recent literature.

The model was applied in several other studies to evaluate landscape and ecosystem functioning and the effects of land and reservoir management on the water and sediment export of large dryland catchments in Spain and north-eastern Brazil (see Table 9 for a summary of current applications). These studies include for example the assessment of spatial and temporal variability of water and sediment connectivity for a $933 \mathrm{~km}^{2}$ dryland basin in the semi-arid northeast of Brazil (Medeiros et al., 2010), the analysis of bedload transport characteristics and ecosystem stability due to afforestation for a $65 \mathrm{~km}^{2}$ mountainous catchment (Mueller et al., 2008, 2009) and the effects of a network of small reservoirs on water and sediment yield in a dryland catchment (Mamede, 2008). By reviewing the previous model applications (references in Table 8), several shortcomings of WASA-SED become apparent and recommend caution as with any model application at large scales. Uncertainties in process descriptions existed with regard to processes in inter-storm periods such as the soil moisture dynamics under different vegetation cover (Mueller et al., 2009) and the erosion processes that are governed by the weathering, freezing and thawing cycles of the upper soil layer (Appel, 2006). In addition, the model contains only limited descriptions of processes which are commonly not regarded to be relevant for dryland settings, but may influence its hydrological regime under certain conditions, such as snow melt and groundwater movement as well as interaction and transmission losses in the riverbed (Francke, 2009).

Considering the merits and limits of WASA-SED, we believe that WASA-SED is a powerful tool to assess erosion export dynamics at the meso-scale and could help to substantially improve the understanding of the processes that lead to reservoir sedimentation and the subsequent reduction of water availability in dryland environments.

Acknowledgements. This research was carried out within the SESAM (Sediment Export from Semi-Arid Catchments: Measurement and Modelling) project and was funded by the Deutsche Forschungsgemeinschaft (DFG). Authors gratefully acknowledge the work done by two anonymous reviewers whose comments greatly improved the original version of the manuscript.

Edited by: D. Lunt

\section{References}

Ackers, P. and White, W. R.: Sediment transport: new approach and analysis, J. Hydr. Eng. Div.-ASCE, 99, 2041-2060, 1973.

Appel, K.: Characterisation of badlands and modelling of soil erosion in the Isabena watershed, NE Spain, unpublished M.Sc. thesis, University of Potsdam, Germany, available at: http://brandenburg.geoecology.uni-potsdam.de/projekte/ sesam/reports.php, 2006. 
Arnold, J. G., William, J. R., Nicks, A. D., and Sammons, N. B.: SWRRB (A basin scale simulation model for soil and water resources management), User's Manual, Texas A\&M University Press, 195 pp., USA, 1989.

Arnold, J. G., Williams, J. R., and Maidment, D. R.: Continuoustime water and sediment-routing model for large basins, J. Hydraul. Eng., 121, 171-183, 1995.

Bagnold, R. A.: The flow of cohesionless grains in fluids, Philos. T. R. Soc. Lond. A, 249, 235-297, 1956.

Batalla, R. J., Garcia, C., and Balasch, J. C.: Total sediment load in a Mediterranean mountainous catchment (the Ribera Salada River, Catalan Pre-Pyrenees, NE Spain), Z. Geomorphol., 49(4), 495-514, 2005.

Beven, K.: Rainfall-runoff modelling. The primer, John Wiley \& Sons, Chichester, UK, 2001.

Boardman, J. and Favis-Mortlock, D.: Modelling soil erosion bywater, Series I: Global Environmental Change, Springer, Berlin, 55, 531 p., 1998.

Breuer, L., Eckhardt, K., and Frede, H.-G.: Plant parameter values for models in temperate climates, Ecol. Model., 169, 237-293, 2003.

CHEBRO: La Confederacion hidgroafica del Ebro, Zaragoza, Spain, 2002 (in Spanish).

CHEBRO: Mapa "Fondos Aluviales" 1:50 000, available at: http: //www.chebro.es/ContenidoCartoGeologia.htm (last access: 1 April 2010), 1993 (in Spanish).

CHEBRO: Usos de Suelos (1984/1991/1995) de la cuenca hidrografica del Ebro; 1:100 000, Consultora de M. Angel FernándezRuffete y Cereyo, Oficina de Planificación Hidrológica, C.H.E., available at: http://www.chebro.es/ (last access: 1 April 2010), 1998 (in Spanish).

CSIC/IRNAS: Mapa de suelos (Clasificacion USDA, 1987), 1:1 Mio, Sevilla, SEISnet-website, available at: http://www.irnase. csic.es/ (last access: 1 April 2010), 2000 (in Spanish).

Chow, V. T., Maidment, D. R., and Mays, L. W.: Applied Hydrology, in: Civil Engineering Series, McGraw-Hill Int. eds., Singapore, 1988.

De Roo, A. P. J., Wesseling, C. G., and Ritsema, C. J.: LISEM: a single event physically-based hydrologic and soil erosion model for drainage basins. I: Theory, input and output, Hydrol. Processes, 10, 1107-1117, 1996.

Everaert, W.: Empirical relations for the sediment transport capacity of interrill flow, Earth Surf. Proc. Land., 16, 513-532, 1991.

FAO: Global and national soils and terrain digital databases (SOTER), Procedures Manual, World Soil Resources Reports, No. 74., FAO (Food and Agriculture Organization of the United Nations), Rome, Italy, 1993.

FAO: Global Soil and Terrain Database (WORLD-SOTER), FAO, AGL (Food and AgricultureOrganization of the United Nations, Land and Water Development Division), available at: http:// www.fao.org/ag/AGL/agll/soter.htm., 2001.

Foster, G. R. and Wischmeier, W. H.: Evaluating irregular slopes for soil loss prediction, T. ASAE, 17, 305-309, 1974.

Francke, T., Güntner, A., Bronstert, A., Mamede, G., and Müller, E. N.: Automated catena-based discretisation of landscapes for the derivation of hydrological modelling units, Int. J. Geogr. Inf. Sci., 22, 111-132, 2008.

Francke, T., López-Tarazón, J. A., Vericat, D., Bronstert, A., and Batalla, R. J.: Flood-Based Analysis of High-Magnitude Sed- iment Transport Using a Non-Parametric Method, Earth Surf. Proc. Land., 33(13), 2064-2077, 2008.

Francke, T.: Measurement and Modelling of Water and Sediment Fluxes in Meso-Scale Dryland Catchments, Ph.D. thesis, Universität Potsdam, Potsdam, available at: http://nbn-resolving.de/ urn:nbn:de:kobv:517-opus-31525, 2009.

Gallart, F., Solé, A., Puigdefábregas, J., and Lázaro, R.: Badland Systems in the Mediterranean, in: Dryland rivers, edited by: Bull, L. J. and Kirkby, M. J., Hydrology and Geomorphology of Semi-arid Channels, 299-326, 2002.

Graf, W. H. and Altinakar, M. S.: Fluvial hydraulics - flow and transport processes in channels of simple geometry, John Wiley \& Sons LTDA, ISBN 0-471-97714-4, 1998.

Green, W. H. and Ampt, G. A.: Studies on soil physics I. The flow of air and water through soils, J. Agr. Sci, 4, 1-24, 1911.

Güntner, A.: Large-scale hydrological modelling in the semi-arid North-East of Brazil, Dissertation, Institut für Geoökologie, Universität Potsdam, PIK-Report, Nr. 77, 2002.

Güntner, A. and Bronstert, A.: Representation of landscape variability and lateral redistribution processes for large-scale hydrological modelling in semi-arid areas, J. Hydrol., 297, 136-161, 2004.

Güntner, A., Krol, M. S., Araújo, J. C. d., and Bronstert, A.: Simple water balance modelling of surface reservoir systems in a large data-scarce semiarid region, Hydrol. Sci. J., 49(5), 901918, 2004.

Haan, C. T., Barfield, B. J., and Hayes, J. C.: Design hydrology and sedimentology for small catchments, Academic Press, San Diego, CA, 1994.

Han, Q. W.: A study on the non-equilibrium transportation of suspended load, Proc. Int. Symps. on River Sedimentation, Beijing, China, 2, 793-802, 1980.

Han, Q. and He, M.: A mathematical model for reservoir sedimentation and fluvial processes, Int. J. Sediment Res., 5, 43-84, 1990.

IRTCES: Lecture notes of the training course on reservoir sedimentation. International Research of Training Center on Erosion and Sedimentation, Sediment Research Laboratory of Tsinghua University, Beijing, China, 1985.

Jetten, V.: LISEM user manual, version 2.x. Draft version January 2002. Utrecht Centre for Environment and Landscape Dynamics, Utrecht University, The Netherlands, 48 pp., 2002.

Kirkby, M. J.: Physically based process model for hydrology, ecology and land degradation, in: Mediterranean Desertification and Land Use, edited by: Brandt, C. J. and Thornes, J. B., Wiley, UK, 1997.

Krysanova, F., Wechsung, J., Arnold, R., Srinivasan, J., and Williams, J.: SWIM (Soil and Water Integrated Model), User Manual, PIK Report Nr. 69, 239 pp., 2000.

López-Tarazón, J. A., Batalla, R. J., Vericat, D., and Francke, T.: Suspended sediment transport in a highly erodible catchment: The river Isabena (Central Pyrenees), Geomorphology, 109, 210-221, 2009.

Mamede, G.: Reservoir sedimentation in dryland catchments: Modelling and management, $\mathrm{PhD}$ thesis, University of Potsdam, Germany, published on: http://opus.kobv.de/ubp/volltexte/2008/ 1704/, 2008.

Maidment, D. R.: Handbook of hydrology, MGraw-Hill, 1424 pp., New York, 1993. 
Medeiros, P., Guntner, A., Francke, T., Mamede, G., and de Araujo, J. C.: Modelling spatio-temporal patterns of sediment yield and connectivity in a semi-arid catchment with the WASA-SED model, Hydrol. Sci. J., accepted, 2010.

Meyer-Peter, E. and Müller, R.: Formulas for bedload transport, Proc. International Association of Hydraulic Research, 3rd Annual Conference, Stockholm, 39-64, 1948.

Morgan, R. P. C.: Soil erosion and conservation Longman Group, UK, Limited, 304 pp., 1995.

Morgan, R. P. C., Quinton, J. N., Smith, R. E., Govers, G., Poesen, J. W. A., Auerswald, K., Chisci, G., Torri, D., and Styczen, M. E.: The European Soil Erosion Model (EUROSEM): a dynamic approach for predicting sediment transport from fields and small catchments, Earth Surf. Proc. Land., 23, 527-544, 1998.

Müller, E. N., Batalla, R. J., and Bronstert, A. Dryland river modelling of water and sediment fluxes using a representative river stretch approach, Book chapter IN: Natural Systems and Global Change, German-Polish Seminar Turew, Poznan, 2006.

Mueller, E. N., Francke, T., Batalla, R. J., and Bronstert, A.: Modelling the effects of land-use change on runoff and sediment yield for a meso-scale catchment in the Southern Pyrenees, CATENA, 79, 288-296, 2009.

Mueller, E. N., Batalla, R. J., Garcia, C., and Bronstert, A.: Modelling bedload rates from fine grain-size patches during small floods in a gravel-bed river, J. Hydrol. Eng., 134, 1430-1439, 2008.

Mueller, E. N.: Quantification of transient sediment storage in the riverbed for a dryland setting in NE Spain, SESAM Internet Resources, available at: http: //brandenburg.geoecology.uni-potsdam.de/projekte/sesam/ download/Projects/Project_Transient_Sediment_Storage.pdf, 2008.

Nash, J. E. and Sutcliffe, V.: River flow forecasting through conceptual models, I. A discussion of principles, J. Hydrol., 10, 282290, 1970.

Neitsch, S. L., Arnold, J. G., Kiniry, J. R., Williams, J. R., and King, K. W.: Soil and Water Assessment Tool, Theoretical Documentation, Version 2000, Published by Texas Water Resources Institute, TWRI Report TR-191, 2002.

Quinton, J.: Erosion and sediment transport, Book chapter in: Finding simplicity in complexity, edited by: Wainwright, J. and Mulligan, M., Environmental Modelling, John Wiley \& Sons, Chichester, UK, 2004.

Rickenmann, D.: Comparison of bed load transport in torrents and gravel bed streams, Water Resour. Res., 37, 3295-3305, 2001.
Schaap, M. G., Leij, F. J., and van Genuchten, M. Th.: ROSETTA: a computer program for estimating soil hydraulic parameters with hierarchical pedotransfer functions, J. Hydrol., 251, 163-176, 2001.

Schmidt, J.: A mathematical model to simulate rainfall erosion, Catena Suppl., 19, 101-109, 1991.

Schoklitsch, A.: Handbuch des Wasserbaus, 2nd edn., Springer, Vienna, 257 pp., 1950.

Shuttleworth, J. and Wallace, J. S.: Evaporation from sparse crops - an energy combination theory, Q. J. Roy. Meteorol. Soc., 111, 839-855, 1985.

Sivapalan, M., Viney, N. R., and Jeevaraj, C. G.: Water and salt balance modelling to predict the effects of land use changes in forested catchments. 3. The large scale model, Hydrol. Processes, 10, 429-446, 1996.

Smart, G. M. and Jaeggi, M. N. R.: Sediment transport on steep slopes, Mitteil. 64, Versuchsanstalt für Wasserbau, Hydrologie und Glaziologie, ETH-Zürich, Switzerland, 1983.

Sidorchuk, A.: A dynamic model of gully erosion, in: Modelling soil erosion by water, edited by: Boardman, J. and FavisMortlock, D., NATO-Series I, Berlin, Heidelberg, 55, 451-460, 1998.

Sidorchuk, A. and Sidorchuk, A.: Model for estimating gully morphology, IAHS Publ., Wallingford, 249, 333-343, 1998.

USDA-SCS: USDA-SCS, Ephemeral Gully Erosion Model. EGEM. Version 2.0 DOS User Manual, Washington, 1992.

Valero-Garcés, B. L., Navas, A., Machín, J., and Walling, D.: Sediment sources and siltation in mountain reservoirs: a case study from the Central Spanish Pyrenees, Geomorphology, 28, 23-41, 1999.

Von Werner, K.: GIS-orientierte Methoden der digitalen Reliefanalyse zur Modellierung von Bodenerosion in kleinen Einzugsgebieten, Dissertation, Inst. f. Geographische Wissenschaften, TU Berlin, 1995.

Williams, J.: The EPIC Model, in: Computer Models of Watershed Hydrology, edited by: Singh, V. P., Water Resources Publications, Highlands Ranch, CO, 909-1000, 1995.

Wu, W., Rodi, W., and Wenka, T.: 3-D numerical modeling of flow and sediment transport in open channels, J. Hydrol. Eng., 126, 4-15, 2000.

Wischmeier, W. and Smith, D.: Predicting rainfall erosion losses, US Gov. Print. Off, Washington, 1978.

Yang, C. T. and Simoes, F. J. M.: User'smanual for GSTARS3 (Generalized Sediment Transport model for Alluvial River Simulation version 3.0), US Bureau of Reclamation Technical Service Center, Denver, CO, 80225, 2002. 